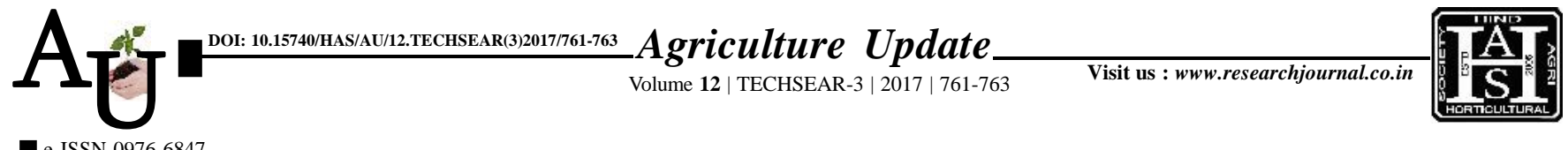

\title{
Research Article: Survey on incidence of soil borne diseases of coriander (Coriandrum sativum L.) in major districts of Andhra Pradesh
}

\author{
M.S.V. SATYANARAYANA, K. GOPAL, M. KAVITHA, CH. RUTH AND SYED \\ SADARUNNISA
}

Article Chronicle:

Received :

10.07.2017;

Accepted :

25.07.2017

KEY WoRds:

Fusarium

solani,Fusarium

oxysporum f.sp.

corianderi,

Coriander, Root rot,

Wilt, Survey

\section{Author for correspondence :}

M.S.V. SATYANARAYANA

Department of Plant Pathology, College of

Horticulture, Dr. Y.S.R.

Horticultural University, ANANTHARAJUPETA

(A.P.) INDIA

Email :

shivamaaragaani7@

gmail.com

See end of the article for authors' affiliations
SUMMARY : Coriander (Coriandrum sativum L.) an important annual herb used extensively all over the world. It is cultivated intensively in the districts of Kurnool, Guntur, Prakasam, Ananthapur, Chittor and Kadapa of A.P in India.Four districts of A.P were surveyed to record the disease incidence of soil borne diseases in coriander. Root rot and wilt are important soil borne diseases prevalently causing yield loss in most of coriander growing fields which ultimately causes rotting of roots and wilting of plants.Highest disease incidence (\%) of root rot and wilt was observed in Kurnool district (38.79\%) (10.35\%) respectively.Fusarium solani and Fusarium oxysporum f.sp. corianderi were isolated from the diseased samples and identified based on their cultural and morphological characters. These diseasescausing a direct loss in its productivity with an incidence of root rot ranged from 26-38\% and wilt rangedf rom $2-10 \%$.

How to cite this article : Satyanarayana, M.S.V., Gopal, K., Kavitha, M., Ch. Ruth and Sadarunnisa, Syed (2017). Survey on incidence of soil borne diseases of coriander (Coriandrum sativum L.) in major districts of Andhra Pradesh. Agric. Update, 12(TECHSEAR-3) : 761-763; DOI: 10.15740/HAS/AU/12.TECHSEAR(3)2017/ 761-763. 